\title{
Instruments of foreign policy in the post-bipolar system of international relations
}

UDC 327.1:«1991/2019»

DOI https://doi.org/10.24195/2414-

9616.2020-3.22

Sedliar Yuliia Oleksandrivna

Doctor of Political Sciences,

Professor at the Department

of Administrative and Constitutional Law

Admiral Makarov National University

of Shipbuilding

Heroes of Ukraine str., 9, Mykolaiv,

Ukraine

Yaroshenko Vira Mykolaivna

Candidate of Political Science,

Associate Professor at the Department of Social Work

V. O. Sukhomlynskyi Mykolaiv National University

Nikolskaya str., 24, Mykolaiv, Ukraine
It is undeniable that economic sanctions have become an international relations tool of choice in the post-bipolar era. The range of nations that have become targets of this foreign policy instrument is growing month by month, as is the list of those states applying the sanctions. This rush to sanction has generated a great deal of criticism in both academic circles and among the multinational firms that are typically the bearers of a large part of the implicit taxation that economic sanctions represent. It is a reasonable generalization to characterize international economic sanctions as overused, ineffective, and unfair. Nevertheless, this characterization of sanctions is a generalization. In order to more fully understand what should be used and what should not, what is effective and what is not, and what is fair and what is not, a better understanding of what economic sanctions do is necessary. The objective of this study was to establish influence of non-military instruments on contemporary international relations. It opens with the review of coercive economic tools and then goes on to explore the impact of soft power on the world policy. The article surveys the definitional issues of the economic sanctions in the international relations theory. It gives a review of the conceptual background of the economic sanctions through the prism of the classical methodological approaches of international relations theory and then goes on to explore the variables of the efficiency of economic sanctions as foreign policy tool. Then article scrutinizes of what soft power is and what are the origins and sources of soft power in contemporary international relations. Then the compound elements of soft power and its implications are analyzed. The authors explain the relations between soft power and smart power, focuses on historical context in which the concept of soft power was formulated, discuss the contemporary communication strategies in international relations. In conclusion the authors advocate the idea of necessity for Ukrainian diplomacy to pay more attention on elements of soft power, sanctions strategy and stress that in contemporary world policy the soft power may become not only an effective tool to secure national interests of Ukraine but the mean to deter Russian influence.

Key words: foreign policy, international relations theory, economic sanctions, soft power, smart power, foreign policy of Ukraine, communication strategies.
Introduction. For the past years non-military influence (economic sanctions and soft power) acquired growing prominence in foreign policy of the great powers. The US, the EU, China and Japan employ non-military tools in responding to the Iranian and North Korean nuclear crises that threaten their security. Non-military instruments these are means of great powers by which they seek to influence the behavior of target states, to demonstrate leadership, to resolve international conflict and to express common values. Above all, because economic rather than military strength is increasingly seen by states as the prime determinant of international power, non-military tools may begin to assume an even more prominent role.

Problems of formation and development of the sanctions policy were researched mainly by foreign scientists, such as J. Blanchard, D. Cortright, D. Drezner, J. Galtung, G. Lopez, M. O'Sullivan, R. Pape, N. Ripsman, et al. Nevertheless, scientific understanding of sanctions policy has a different vision and conceptual structure depending within which framework of theoretical school this concept is considered. But whatever the school, there is a general agreement among experts that under definite circumstances sanctions strategy is capable not only to guarantee state's national interests but to maintain international peace and security. Among Ukrainian scholars, the issues of sanctions strategy are widely outlined in the publications of S. Galaka, V. Pahil,
Yu. Romanenko, V.Vasilenko, and others. Soft power has become part of popular political discourse since it was coined by Harvard's Joseph Nye in his 1990 book, Bound to Lead: The Changing Nature of American Power, strengthened by his Soft Power: The Means to Success in World Politics, and further elaborated in The Powers To Lead [12-17].

The purpose of this research is to analyze the nature of non-military instruments (economic sanctions, soft power and communication strategies) of foreign policy within the international relations theory, because these tools are becoming increasingly central to shaping strategic outcomes in the XXI century.

The research is based on the groups of methods. The study used a case study approach, comparative approach, methods of textual analysis and generalization.

Results. At first, we will try to conceptualize the definition of the economic sanctions in the international relations theory. There is no generally accepted definition of economic sanctions. The term "economic sanctions" is one of the more confused and confusing to have entered the lexicon and discourse of international politics. Part of the ambiguity surrounding the term stems from the fact that the word "sanctions" in everyday usage carries multiple meanings. According to the Oxford Concise Dictionary, the term can connote the granting of official permission or approval and, at the same time, a penalty or punishment 
for disobeying a law or rule $[1 ; 3, p .11]$. Confusion also results from the tendency of many scholars to use the term "sanctions" interchangeably with a raft of other descriptors, such as "economic statecraft", "economic coercion", "economic warfare", "economic diplomacy" [2; 4, p. X]. In the view of the above different definitions of economic sanctions we will analyze more thoroughly.

For instance, Daniel Drezner, a towering figure who made path breaking and enduring contributions to political analysis of the economic sanctions, the author of the "sanctions paradox", defines economic sanctions as "the threat or act by a nationstate or coalition of nation-states, called the sender, to disrupt economic exchange with another nationstate, called the target, unless the targeted country acquiesces to an articulated political demand" [2, p. 2]. R.J. Ellings ascertains economic sanctions as the governmental policies that cut or curtail economic relations in order to coerce the target country(ies) into behaving in accordance with the sanctioner's(s') objectives [5, p. 16]. G. Lopez and D. Cortright qualify economic sanctions as the "coercive foreign policy action of a nation(s) in which it intentionally suspends customary economic relations such as trade and/or financial exchanges in order to prompt the targeted nation to change its policy or behavior [5, p. 15]. N. Crawford determines economic sanctions as "the denial of customary interactions (strategic, economic, or social); they are intended to promote social, political, or economic change in a target state" [6, p. 5]. According to J. Blanchard, N. Ripsman and Shambaugh, economic sanctions strategy is the particular form of the coercive foreign policy in which a state disrupts its normal economic relations with another state in order to achieve one of the following objectives: (1) to induce the targeted state to change its behavior; (2) to generate popular pressure on the government that causes it to change its policies; or (3) to provoke a coup or revolt that leads to the emergence of a new government that will act in accordance with the sanctioning state's wishes [7, p. 219; 8, p. 4]. Rennack evaluates economic sanctions like "coercive measures imposed by one country, or coalition of countries, against another country, its government or individual entities therein, to bring about a change in behavior or policies [9]. American theorist in economic sanctions policy M. O'Sullivan characterizes economic sanctions as the deliberate withdrawal of normal trade or financial relations for foreign policy purposes [10, p. 12].

Theorists in international politics distinguish economic sanctions from economic wars. For instance, R. Pape illustrates the difference between these two categories. According to the scientist, economic sanctions "seek to lower the economic welfare of a target state by reducing international trade in order to coerce the target government to change its political behaviour" [11, p. 93-94]. By contrast, an economic war takes place "when a state threatens to inflict economic harm... in order to persuade the target state to agree to terms of trade more favorable to the coercing state" [11, p. 94].

Economic sanctions operate in a similar way to military warfare. Both share the same end, the "political disintegration of the enemy so that he gives up the pursuit of his goals. The method used is value deprivation" $[1, p .386]$. The theory foresees a roughly proportionate relation between both phenomena: the more intense the value-deprivation, the more widespread the political disintegration in the target state. J. Galtung explains: "The idea is that there is a limit to how much value deprivation the system can stand, and that once this limit is reached (resulting in a split in leadership or between leadership and people), then political disintegration will proceed very rapidly and will lead to surrender or willingness to negotiate" $[1, p .388]$.

Thus, two central definitional elements can be discerned in the concept of economic sanctions: the coercive measures need to be economic in nature and its aim needs to be political.

On the other hand, it is necessary to underscore that the key methodological issue of identifying the variables of the economic sanctions efficiency remains unresolved in international relations scholarship. None of the classical schools has emerged uncontested through its capacity to provide an unequivocal answer to the puzzle of why economic sanctions in some cases fail to achieve desirable outcome. Generally, the international relations theory determines that the policy of economic sanctions effectiveness as a mechanism of the states' national interests quarantee depends on the wide international political support of the sanctions on the part of the great states on all stages of their implementations. It is provided by the coincidence of their national interests in the target country and foreign political attraction of the geopolitical surrounding states of the target country towards realization of the sanctioned measures. The policy of economic sanctions effectiveness also depends on such a factor as the formed normative and legal base which defines the principles and regulates the peculiarity of the policy of economic sanctions implementation related to the target country. The next factors are: institutional providing of the sanctioned measures realization; export and import dependence of the target country on the state-sanctioner which is often quaranteed by the previous positive political relationships between the state-sanctioner and the objective state. It also depends on the moderation of diplomacy goals the policy of sanctions is aimed at, which are to be corrected in the foreign political activity of the objective state but are not directed on the changing of political regime in the target country. Additional factor is the presence of formed political opposition in the objective country which is oriented on the state which real- 
izes the policy of sanctions, demonstrates readiness to satisfy its goals when the mechanisms of the population influence on making political decisions exist.

In XXI century the processes of globalization and the information revolution led to essential transformation of the international system, which is now composed of three different spheres: a military sphere, where the USA has unipolar control but there are several states with a growing military potential as China and Russia and which are ready to become rivalries to the American presence around the world; an economic sphere, where there is a multipolarity shared by the USA, the European Union and Japan; and a third transnational sphere, where a diversity of state and non-state agents coexist [13, p. 39]. The characteristics of the emerging threats also have their origins in the processes of globalization and the information revolution: their main agents are non-state entities that exist and act in the transnational sphere. If hard power resources can be effective in the military and economic spheres, only soft power can work at the transnational level and in reality of proxy war. For Ukraine which is evolved in a war conflict with Russia the soft power instruments can become effective tools to secure national interests of Kyiv. So in terms of aggravation of Ukrainian-Russian confrontation in its bilateral and multilateral dimensions, the issue of the content and consequences of the soft power mechanism, the soft power mechanism's role in the relations among countries require an in-depth study.

Let now look at theoretical formulation of soft power. The concept of soft power that is well known throughout the world is only the definition used by professor Joseph Nye; nevertheless, it is not the only one and its various definitions are not free of contradictions among them.

Taking into considerations mentioned above, we are addressing the conceptualization of soft power given in Nye's main works.

We will begin with a brief discussion about the nature of power, admittedly one of the most disputed concepts in political science and international relations. Nye opts for a succinct definition: 'power is the ability to influence the behavior of others to get the outcomes one wants' [12, p. 25-29; 13, p. 4-5; 14 , p. 1-5]. This conciseness allows him to focus on other aspects of power in international relations, as he moves on to articulate the distinction between hard and soft power. The concepts are twofold: 'The distinction between hard and soft power is one of degree, both in the nature of the behavior and in the tangibility of the resource' $[12$, p. $267 ; 13$, p. 176 ; 14, p. 7]. This distinction between power behaviors and power resources is the crucial element in Nye's concept of soft power.

Thus, Nye defines soft power as the ability to make others want what you want. In this sense, soft power is the opposite of hard power, the ability to make oth- ers do what you want. As traditionally understood in international relations theories, hard power presupposes an active and direct engagement of the actors involved, expressed by incentives or threats, and is usually related to military force or economic resources. Soft power, which Nye also calls co-optive or indirect power, rests on the attraction a set of ideas exerts, or on the capacity to set political agendas that shape the preferences of others. Therefore, soft power is related to intangible resources like culture, ideologies and institutions [12, p. 31-35].

According to Nye, power behaviors are ways of exercising power. Different types of behavior form a spectrum ranging from command power to co-optive power. Command power is the ability to change what others do, while co-optive power is the ability to shape what others want. Therefore, command power is manifested through acts of coercion and persuasion, and co-optive power can be seen in the attraction exerted by a given agent and his capacity to define political agendas.

The second distinction between hard and soft power deals with the tangibility of power resources. However, the scientist does not apply any specific terminology at this point. Referring to tangibility, Nye uses the terms hard power resources and soft power resources. Hard power resources are well known: population, territory, natural resources, the size of the economy, armed forces, technological development, among others. These are tangible resources. In opposition, soft power resources are characteristically intangible resources: culture, ideology, values and institutions are the most common examples.

It is also worth noting that in all works of Nye there is no discussion on the meaning of tangibility. The question of what would qualify a resource as tangible or intangible is not a simple one. Nye classifies economic resources as tangibles, but an argument could be made that most of the time they do not have a physical existence. A financial agreement lending money to a developing country could save its economy from a major crisis, but it is not easy to see the tangibility of this power resource - especially in credibility crisis, as economists well know. On the opposite side of the spectrum, Nye classifies institutions as intangible resources. It is comprehensible that he might be referring to institutional ideas and what they represent, but some institutions have physical existence, very important and present ones, running projects and programs all over the world. The fact is that Nye leaves the reader with no criteria to address the tangibility of power resources.

In any case, the distinction between hard and soft powerisgiven bytaking togetherthenatureoftheagent's behavior and the tangibility of the resources. However, a serious problem arises directly from this articulation. It has to do with the relation between power behaviors and power resources: "... soft power resources 
tend to be associated with co-optive power behavior, whereas hard power resources are usually associated with command behavior. But the relationship is imperfect" [12, p. 267; 13, p. 176; 14, p. 7]. The logical consequence of the terminology used by Nye is that command power is related to hard power resources, and co-optive power to soft power resources. But these relations do not always hold true: it is possible for command power behavior to utilize intangible soft power resources, in the same sense that co-optive power behavior can make use of tangible hard power resources. Actually, it is even possible that command power creates soft power resources, or that co-optive power creates hard power resources.

On the other hand, it is necessary to stress that the question that is not properly explored in Nye's first books on soft power is the dependence of soft power resources on hard power resources: would soft power resources be effective only when hard power resources exist to sustain them? This question is not answered in the first two books, but in the last one the author underlines: " $\ldots$ soft power does not depend on hard power" $[17 ; 14$, p. 9]. Instead of a theoretical argument, Nye presents examples to justify his statement. First, he presents the Vatican as an unquestionable example of soft power (after recounting Stalin's disdainful question about how many divisions the Pope controls). Other examples are contemporary Norway, Canada and Poland that, according to Nye, have recently displayed a stronger influence on international politics than their hard power resources would predict, due to the use of soft power resources in their foreign policies.

Communication as an element of soft power has a significant impact on foreign policy, both in the policy-making process and at a higher level associated with the nexus of foreign policy and international relations. Communication involves the transmission or conveying of information through a system of symbols, signs, or behavior. Communication connects individuals and groups; (re)constructs the context; and defines, describes, and delineates foreign policy options. The current trends are the synthesis in many areas, with a focus on the psychological processes associated with who communicates, how, to whom, and with what effect in the realm of foreign policy; and with the structural characteristics of communication or discourse. The major areas of publications on foreign policy and communication include: (a) the making of foreign policy and the role of mass media in this process; (b) how foreign policy is understood as a communicated message by allies and adversaries in international relations; and (c) constructivism, poststructuralism, and discourse analysis. Within the scope of foreign policy and media falls work associated with the CNN effect, framing, and public opinion. Works within international relations have focused on how foreign policy signals international intent, including threat and willingness to cooperate [18].
Conclusions. Summing up the above mentioned we admit that economic sanctions as the foreign policy tool that prescribes the disruption of economic relations in order to coerce the target state to change disapproved policy. Theorists assume that the main goal of economic sanctions is to change target country's behavior as desired by a sanctioning state. Thus, scientists suppose that compellence is the main aim which pursues sanctioning country. Other goals of economic sanctions are specific deterrence, weakening, international and domestic symbolism.

Scholars are unanimous in the opinion that economic harm leads to political disintegration brought about by an unwillingness of the population in the target country to suffer economically because of internationally unpopular policy.

Soft power is the use of attraction and persuasion rather than the use of coercion or force in foreign policy. It arises from the attractiveness of a country's culture, political ideals and policies, whereas hard power develops out of a country's military or economic might. Thus, the soft power of a country rests primarily on three resources: its culture (in places where it is attractive to others), its political values (when it lives up to them at home and abroad) and its foreign policies (when they are seen as legitimate and having moral authority). On the other hand, the set of liberal ideas promoted by the USA and shared by other Western states, such as democracy and free markets, made soft power resources easier to implement. With other states sharing the same principles and values, the costs of maintaining the order through economic incentives or military threats were reduced. Once again, development and exercise of soft power made the position of democracy in the contemporary international system less difficult to maintain.

\section{REFERENCES:}

1. Galtung J. (1967) On the Effects of International Economic Sanctions. With Examples from the Case of Rhodesia, World Politics, 19 (3), 378-416.

2. Drezner D. (1999) The Sanctions Paradox. Economic Statecraft and International Relations. $342 \mathrm{p}$.

3. Taylor B. (2010) Sanctions as Grand Strategy. 123p.

4. Weintraub S. (1982) Economic Coercion and US Foreign Policy: Implications of Case Studies from the Johnson Administration. $234 \mathrm{p}$.

5. Ellings, R.J. (1999) The End of Economic Sanctions? in Private Property and National Security: Foreign Economic Sanctions and the Constitution. R.J. Ellings, H. Gregorian, M. Leigh and J.A. Swindler. Washington, DC, The National Legal Center for the Public Interest, 15-29.

6. Crawford N., Klotz A. (1999) How Sanctions Work: Lessons from South Africa. 292 p.

7. Blanchard J., Ripsman N. (2000) Asking the Right Question: When Do Economic Sanctions Work Best?, Security Studies, Winter, 219-253.

8. Shambaugh G.E. (1999) States, Firms, and Power: Successful Sanctions in United States Foreign Policy. $248 \mathrm{p}$. 
9. Rennack D.E. (2000) Economic Sanctions: Legislation in the 106th Congress. Congressional Research Service Reports. URL: http://www.ncseonline.org/nle/ crsreports/international/inter21.cfm?\&CFID $=3378804 \&$ CFTOKE $=48114672$

10. O`Sullivan M. (2003) Shrewd Sanctions: Statecraft and State Sponsors of Terrorism. 424 p.

11. Pape R. (1997) 'Why Economic Sanctions Do Not Work', International Security, (22), Fall, 90-136.

12. Nye Jr.(1990) Bound to Lead: The Changing Nature of American Power, New York: Basic Books. $336 \mathrm{p}$.

13. Nye Jr. (2002) The Paradox of American Power: Why the World's Only Superpower Can't Go it Alone, New York: Oxford University Press. 222 p.
14. Nye Jr. (2004) Soft Power: The Means to Success in World Politics, New York: Public Affairs. Przeworski.

15. Nye Jr. (2007) Notes for A Soft Power Research Agenda, in F. Berenskoetter and M.J. Williams (eds.) Power in World Politics, London: Routledge.

16. Nye Jr. (2008) Public Diplomacy and Soft Power The Annals of the American Academy of Political and Social Science, 94-109.

17. Soft Power and US Foreign Policy: theoretical, historical and contemporary perspectives / edited by M. Cox, London: Routledge. 2010. 249 p.

18. Gilboa E. (2002) Global Communication and Foreign Policy Journal of Communication, December. Pp. 731-748.

\section{Інструменти зовнішньої політики в постбіполярній системі міжнародних відносин}

Седляр Юлія Олександрівна

доктор політичних наук, профресор кафредри адміністративного та конституційного права Національного університету кораблебудування імені адмірала Макарова

вул. Героїв України, 9, Миколаїв, Україна

\section{Ярошенко Віра Миколаївна}

кандидат політичних наук, доцент кафедри соціальної роботи Миколаївського національного університету імені В.О. Сухомлинського вул. Нікольська, 24, Миколаїв, Україна
Беззаперечним є той фракт, що у постбіполярний період міжнародних відносин економічні санкції набули статусу важливого механізму зовнішньополітичного впливу. Практично щоісяця зростає чисельність держав, на які накладаються економічні санкції, так само, як і постійно збільшується кількість держав-ініціаторів санкційних заходів. Така тенденція невпинного зростання санкційного тиску зазнає суттєвої критики як із боку академічного співтовариства, так і з боку транснаціональних компаній, які мають найбільші витрати від економічних санкцій. у зв'язку із цим міжнародні економічні санкції часто називають надмірним неефективним i несправедливим засобом впливу. Тим не менш ия характеристика економічних санкцій є надто узагальненою $і$ не розкриває параметрів застосування санкцій, не визначає, за яких обставин санкційні заходи можуть виявитися ефективним або неефективним інструментом впливу. Альтернативним інструментом зовнішньополітичного впливу в постбіполярний період стали стратегії м'якої сили, які найчастіші застосовують у своїй дипломатії США і держави ЄС. Метою дослідження є визначення ролі і впливу невійськових зовнішньополітичних механізмів на сучасні світові політичні процеси. Виклад розпочинається із висвітлення природи примусових економічних зовнішньополітичних інструментів, надалі розкривається вплив м'якої і розумної сили на специфріку сучасної міжнародної політики. у статmі проаналізовано методологічні підходи, що склалися в теорії міжнародних відносин, до розуміння природи економічних санкцій. З'ясовуються концептуальні підходи, що сорормувалися в рамках класичних напрямів теорії міжнародних відносин, до розуміння сутності санкційного впливу, аналізуються умови ефективності застосування економічних санкцій як інструменту зовнішньої політики. Надалі автори визначають сутність м'якої сили в сучасних міжнародних відносинах, встановлюють співвідношення м'якої і розумної сили як механізмів зовнішньополітичного впливу держав, розкривають історичні передумови появи інструментів м'якої сили у світовій політиці. Наголошується на тому, що в сучасних реаліях протидії російській агресії інструменти м'якої сили й економічні санкції можуть виявитися ефективними засобами відстоювання національних інтересів України.

Ключові слова: зовнішня політика, теорія міжнародних відносин, економічні санкції, м'яка сила, розумна сила, зовнішня політика України, комунікаційні стратегії. 